Vapor Space Characterization of Waste Tank 241-C-107 (In Situ): Results from Samples Collected on 6/17/94
B. D. McVeety
T. W. Clauss
M. W. Ligotke
K. H. Pool
R. B. Lucke
J. S. Young
M. McCulloch
J. S. Fruchter
S. C. Goheen

June 1995

Prepared for Westinghouse Hanford Company under a Related Services Agreement with the U.S. Department of Energy Contract DE-AC06-76RLO 1830

Pacific Northwest Laboratory Operated for the U.S. Department of Energy by Battelle Memorial Institute 
This report was prepared as an account of work sponsored by an agency of the United States Government. Neither the United States Government nor any agency thereof, nor any of their employees, makes any warranty, express or implied, or assumes any legal liability or responsibility for the accuracy, completeness, or usefulness of any information, apparatus, product, or process disclosed, or represents that its use would not infringe privately owned rights. Reference herein to any specific commercial product, process, or service by trade name, trademark, manufacturer, or otherwise does not necessarily constitute or imply its endorsement, recommendation, or favoring by the United States Government or any agency thereof. The views and opinions of authors expressed herein do not necessarily state or reflect those of the United States Government or any agency thereof.

\title{
Vapor Space Characterization of Waste Tank 241-C-107 (In Situ): Results from Samples Collected on 6/17/94
}

\author{
B. D. McVeety \\ T. W. Clauss \\ M. W. Ligotke \\ K. H. Pool \\ R. B. Lucke \\ J. S. Young \\ M. McCulloch \\ J. S. Fruchter \\ S. C. Goheen
}

June 1995

Prepared for Westinghouse Hanford Company

under a Related Services Agreement

with the U.S. Department of Energy

Contract DE-AC06-76RLO 1830

Pacific Northwest Laboratory

Richland, Washington 99352 


\section{DISCLAIMER}

Portions of this document may be illegible in electronic image products. Images are produced from the best available original document. 


\section{Summary}

This report describes the results of organic analyses only from in situ samples obtained from the headspace of the Hanford waste storage Tank 241-C-107 (referred to as Tank C-107) and the ambient air near the tank. The inorganic sorbent trains sampled for this tank were not analyzed due to the presence of internal radioactive contamination of the sorbent trains. The results described here were obtained to support safety and toxicological evaluations. A summary of the results for inorganic and organic analytes is listed in Summary Table 1. Detailed descriptions of the results appear in the text.

Quantitative results for organic compounds were obtained. Seven organic tentatively identified compounds (TICs) were observed above the detection limit of (ca.) $10 \mathrm{ppbv}$, but standards for most of these were not available at the time of analysis, and the reported concentrations are semiquantitative estimates. In addition, we looked for the 40 standard TO-14 analytes. Of these, only a few were observed above the 2-ppbv detection limit. The nine organic analytes with the highest estimated concentrations are listed in Summary Table 1. These nine analytes account for approximately $99 \%$ of the total organic components in Tank C- 107.

Summary Table 1. Summary Results of Organic Samples Collected from the Headspace of Tank C-107 on 6/17/94

\begin{tabular}{|c|c|c|c|}
\hline Category & Analyte & $\begin{array}{l}\text { Vapor }^{(a)} \\
\text { Concentration }\end{array}$ & Units \\
\hline \multirow[t]{9}{*}{ Organic } & Acetone & 0.478 & $\mathrm{mg} / \mathrm{m}^{3}$ \\
\hline & Acetonitrile & 0.143 & $\mathrm{mg} / \mathrm{m}^{3}$ \\
\hline & Methyl benzene (toluene) & 0.125 & $\mathrm{mg} / \mathrm{m}^{3}$ \\
\hline & Alkyl nitrate ${ }^{(b)}$ & 0.096 & $\mathrm{mg} / \mathrm{m}^{3}$ \\
\hline & Alkyl nitrate ${ }^{(c)}$ & 0.068 & $\mathrm{mg} / \mathrm{m}^{3}$ \\
\hline & Propanenitrile & 0.068 & $\mathrm{mg} / \mathrm{m}^{3}$ \\
\hline & Trichlorofluoromethane (FREON-11) & 0.048 & $\mathrm{mg} / \mathrm{m}^{3}$ \\
\hline & 2-Butanone & 0.037 & $\mathrm{mg} / \mathrm{m}^{3}$ \\
\hline & Methyl chloride ${ }^{(d)}$ & 0.013 & $\mathrm{mg} / \mathrm{m}^{3}$ \\
\hline
\end{tabular}

(a) Vapor concentrations were determined using sample-volume data provided by Westinghouse Hanford Company and are based on averaged data.

(b) Compound class at retention time 10.53 .

(c) Compound class at retention time 15.14 .

(d) Although this analyte was detected, it was below the method quantitation limit. 


\section{Acknowledgments}

The authors gratefully acknowledge the support of other project staff at Pacific Northwest Laboratory who contributed to the successful completion of this sampling and analysis activity. Jeff Edwards served as the PNL single-point-of-contact and coordinated sample handling and communications with Westinghouse Hanford Company. Kris B. Olsen performed data analysis. Georgia K. Ruebsamen provided word processing support. 



\section{Abbreviations}

$\begin{array}{ll}\text { CAS } & \text { Chemical Abstracts Service } \\ \text { COC } & \begin{array}{l}\text { chain of custody } \\ \text { EPA }\end{array} \\ \text { U.S. Environmental Protection Agency } \\ \text { GCAMS } & \text { gas chromatography/mass spectrometry } \\ \text { HEPA } & \text { high-efficiency particulate air (filter) } \\ \text { HP } & \text { Hewlett Packard } \\ \text { IS } & \text { internal standard } \\ \text { ISS } & \text { in situ sampling system } \\ \text { PNL } & \text { Pacific Northwest Laboratory } \\ \text { ppbv } & \text { part per billion by volume } \\ \text { SAF } & \text { Sample Analysis Form } \\ \text { STP } & \text { standard temperature and pressure } \\ \text { TIC } & \text { tentatively identified compound } \\ \text { WHC } & \text { Westinghouse Hanford Company }\end{array}$



Contents

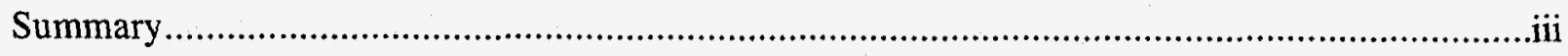

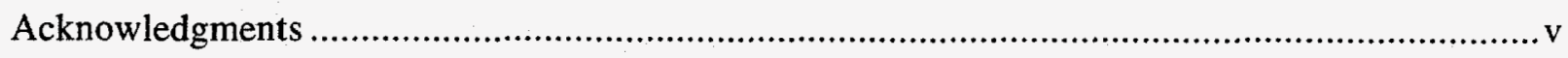

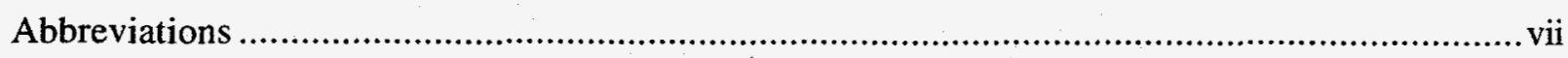

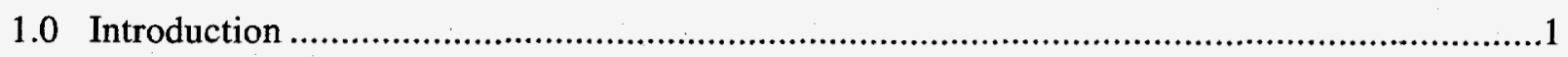

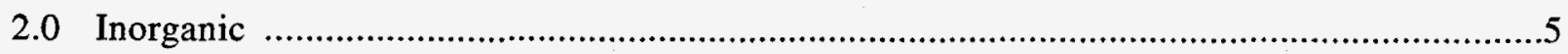

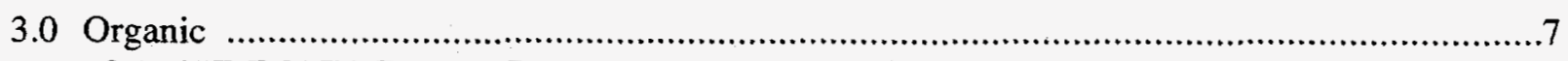

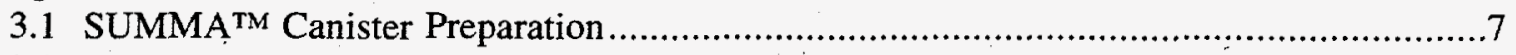

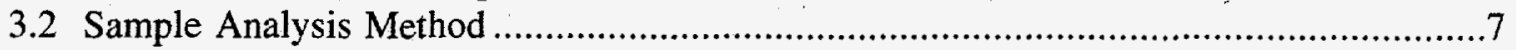

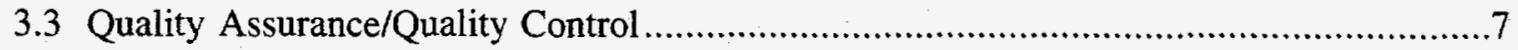

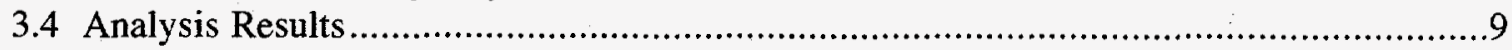

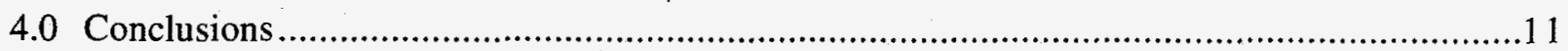

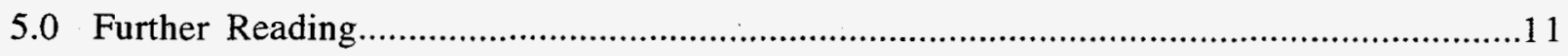

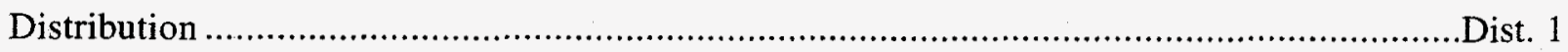




\section{Tables}

3.1 TO-14 Analysis Results for In Situ Samples Collected

from the Headspace of Tank C-107 in SUMMATM Canisters on 6/17/94 .........................12

3.2 Tentatively Identified Compounds and Estimated Concentrations

in the Headspace of Tank C-107 In Situ SUMMA ${ }^{\text {TM }}$ Canister Sample

Collected on $6 / 17 / 94$.

3.3 TO-14 Analysis Results for Ambient Samples Collected Near Hanford

Waste Tank C-107 in a SUMMA ${ }^{\mathrm{TM}}$ Canister on 6/17/94 14

Figures

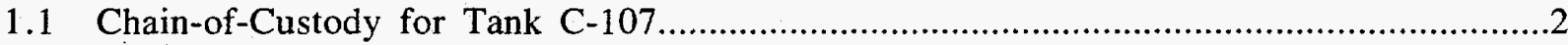

3.1 Total Ion Chromatogram of Hanford Waste Tank C-107 In Situ SUMMATM

Canister Sample S4029--.-140 Collected on 6/17/94. .15 


\subsection{Introduction}

This report describes results of the analyses of tank-headspace samples taken from the Hanford waste Tank 241-C-107 (referred to as Tank C-107). Pacific Northwest Laboratory (PNL) ${ }^{(a)}$ contracted with Westinghouse Hanford Company (WHC) to provide sampling devices and to analyze inorganic and organic analytes collected from the tank headspace and ambient air near the tank. The sample job was designated S4024, and samples were collected by WHC on June 17, 1994, using the in situ sampling system (ISS).

Sampling devices, including four sorbent trains (for inorganic analyses) and four SUMMA ${ }^{\text {TM }}$ canisters (for organic analyses) were supplied to the WHC sampling staff on June 14. Samples were taken (by WHC) from the tank headspace on June 17 and were returned to PNL from the field on June 29. Inorganic (sorbent trap) samples were delivered to PNL on chain of custody (COC) 006888 (see Figure 1.1a). Four SUMMA ${ }^{\mathrm{TM}}$ canisters were delivered on COC No. 006897 (see Figure 1.1b). One SUMMATM canister, S4029-A01-113, was delivered on WHC COC 006418. Canister S4029A01-113 was originally to be part of Sample Job 7B for Tank C-103 on COC 006876. Instead, the canister was used for this sample job when an additional canister was needed in the field. The four SUMMA ${ }^{\mathrm{TM}}$ and all sorbent samples were originally prepared to be used for Tank C-110/S4041 before reassigning to Tank C-107. The Sample Analysis Form (SAF) number on COC 006888 was originally S4041. The number was changed by WHC to S4029 on June 29, 1994. However, the sample numbers on the form were not changed. To avoid confusion, for the purpose of this report, the samples will be identified as SAF S4029. Canister S4029----138 was an ambient air sample collected upwind of Tank C-107. SUMMA ${ }^{\mathrm{TM}}$ canister sample No. S4024-024-083 was taken as a surrogate sample. Westinghouse Hanford Company and PNL agreed that analysis of the surrogate sample was not required.

The samples were inspected upon delivery to the 326/23B laboratory and logged into PNL record book 55408 before implementation of PNL Technical Procedure PNL-TVP-0 $7^{(\mathrm{b})}$. The sorbent traps were found to contain levels of smearable radioactivity exceeding our standard inorganic laboratory capacity. The sorbent traps were not accepted by PNL. Instead, they were returned to WHC for disposal. The SUMMA ${ }^{\mathrm{TM}}$ canisters were found to be free of radiation contamination and were stored in the $326 / 23 \mathrm{~B}$ laboratory at ambient $\left(25^{\circ} \mathrm{C}\right)$ temperature until the time of analysis. Access to the 326/23B laboratory is limited to PNL personnel working on the wastetank safety program. Analyses described in this report were performed at PNL in the 300 area of the Hanford Reservation. Analytical methods that were used are described in the text. Organic analyses were performed using cryogenic preconcentration followed by gas chromatography/mass spectrometry (GC/MS).

(a) Pacific Northwest Laboratory is operated for the U. S. Department of Energy by Battelle Memorial Institute under Contract DE-AC06-76RLO 1830.

(b) PNL-TVP-07, Rev. 0, October 1994, Sample Shipping and Receiving Procedure for PNL Waste Tank Samples, PNL-Technical Procedure, Tank Vapor Project, Richland, Washington. 


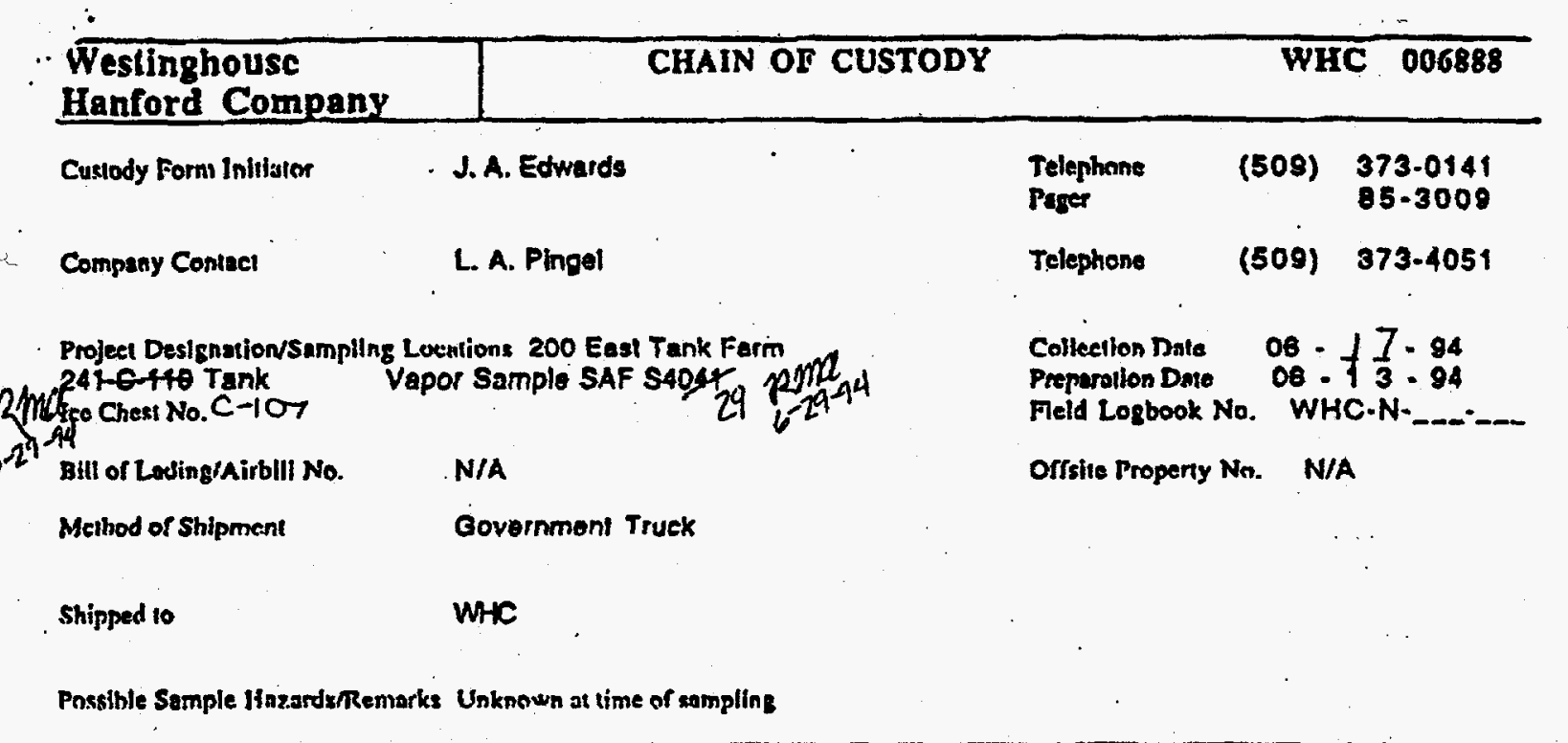

Sample dentilication

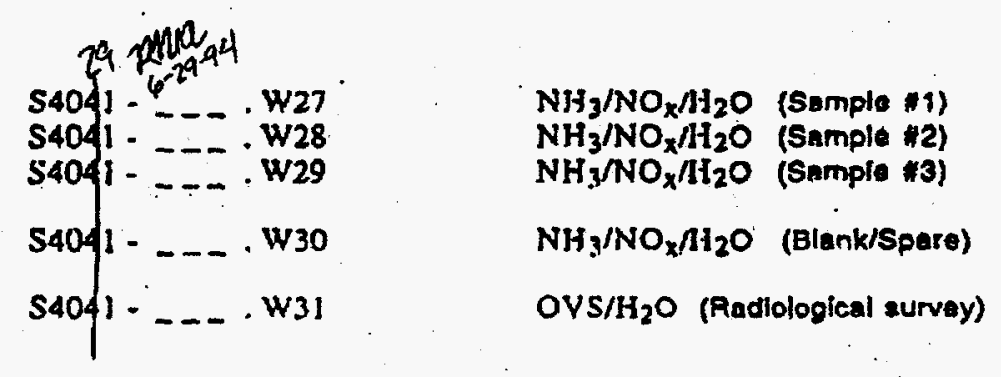

\begin{tabular}{|c|c|c|c|c|c|}
\hline \multicolumn{2}{|l|}{ IX] field Transfer of Cuslody } & I Chain or Ponsession & \multicolumn{3}{|c|}{ (Slen end Prinl Numes) } \\
\hline 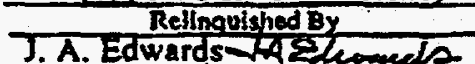 & $\frac{\text { Yare }}{06.1494}$ & $\frac{\text { Time }}{845 \mathrm{Am}}$ & $\begin{array}{r}\text { Raceived lyy } \\
\pi / \beta\end{array}$ & $\frac{\text { Dave }}{\frac{1}{-N-S C}}$ & Time \\
\hline 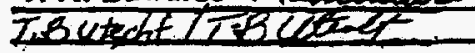 & $06-2994$ & 1000 & hrode satemed & $6=2,94$ & 1000 \\
\hline & & & & & \\
\hline & & & & & \\
\hline & & & & & \\
\hline
\end{tabular}

Final Sample Disposition

Disposal Method:

Disposed by:

DaterTime:

Comments

WHC cest -

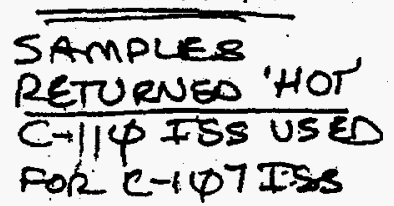

A.6000-407 (1292) WEP061

Figure 1.1a Chain-of-Custody for Inorganic Samples from Tank C-107 


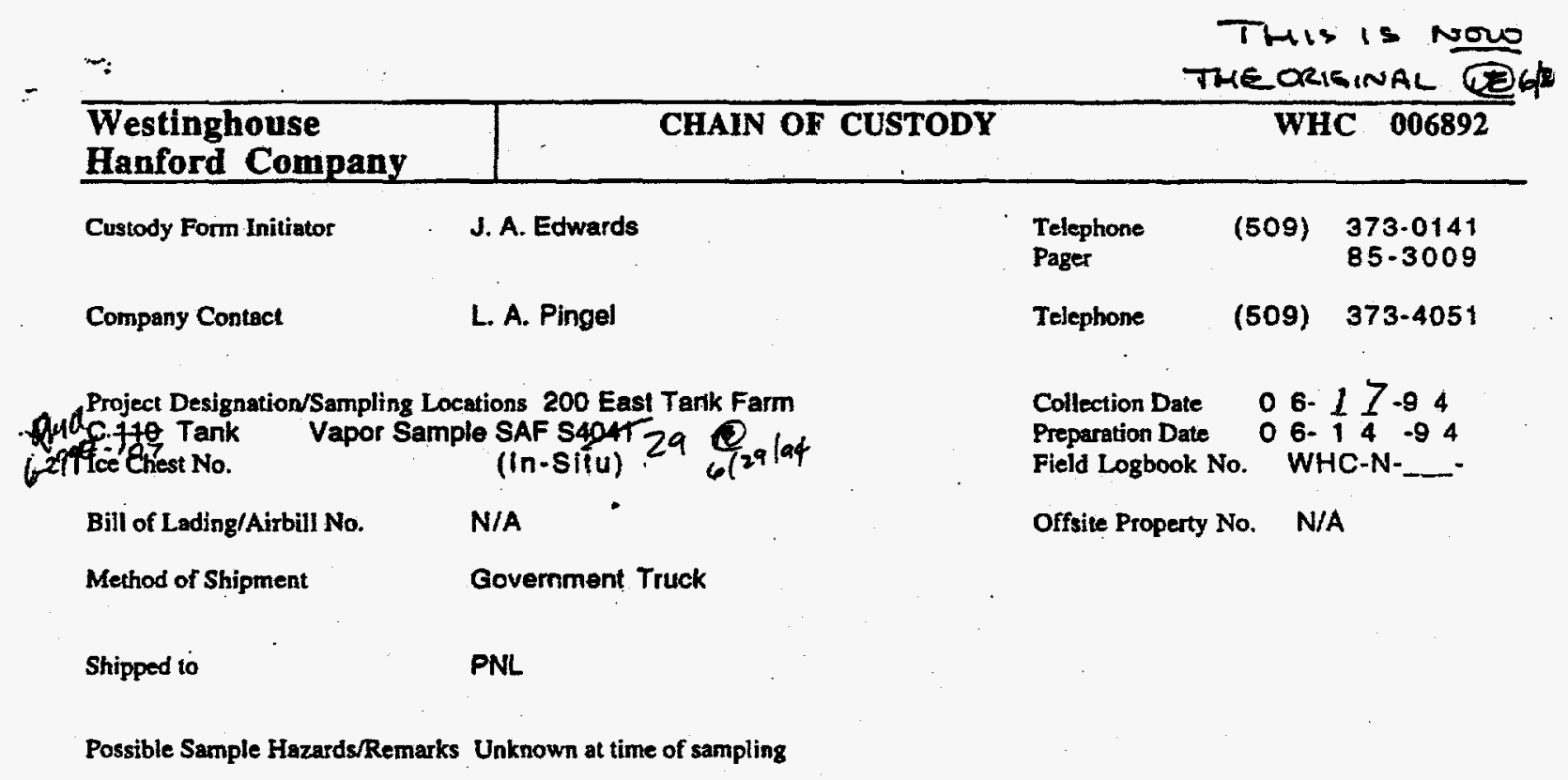

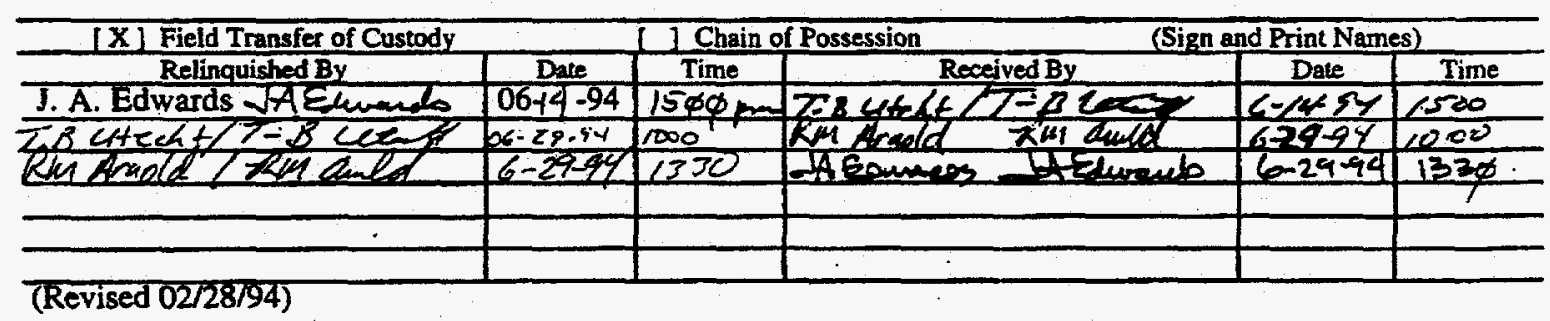

Final Sample Disposition

Disposal Method:

Disposed by:

Date/Time:

A-6000.407 (12/92) WEF06]

Figure 1.1b Chain-of-Custody for Organic Samples from Tank C-107 
This is now the

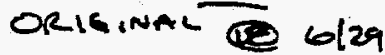

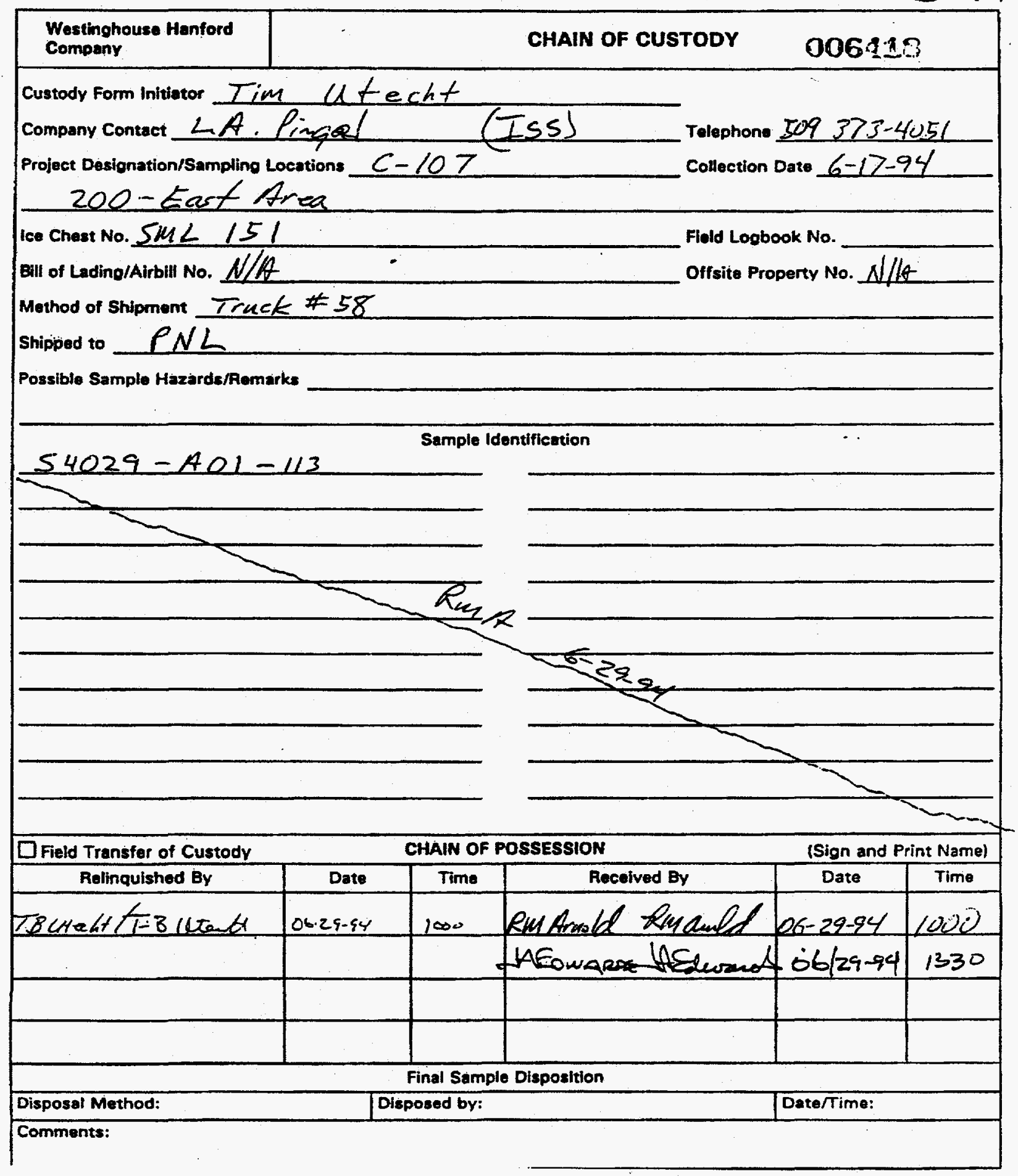

Figure 1.1c Chain-of-Custody for Organic Samples from Tank C-107 


\subsection{Inorganic}

Solid sorbent trains for ammonia $\left(\mathrm{NH}_{3}\right)$, nitrogen dioxide, $\left(\mathrm{NO}_{2}\right)$, nitric oxide $\left(\mathrm{NO}_{\mathrm{x}}\right)$, and water $\left(\mathrm{H}_{2} \mathrm{O}\right)$ were supplied. The sorbent trains were originally intended for Tank $\mathrm{C}-110$ but used to sample C-107 because of a change in operations imposed by WHC. The traps were inserted into the waste tank and used to sample the tank headspace. Available information from a radiological survey of the samples indicated the presence of internal contamination. The samples were not analyzed. To reduce the possibility of contamination in subsequent sample jobs, a wrapped high-efficiency particulate air (HEPA)-filtered inlet manifold has since been designed for use upstream of in situ sorbent trains. 



\subsection{Organic}

\subsection{SUMMA ${ }^{\mathrm{TM}}$ Canister Preparation}

Before sending SUMMA ${ }^{\mathrm{TM}}$ canisters out to the field for sampling, the canisters are cleaned and verified contaminant free according to PNL Technical Procedure PNL-TVP-02 ${ }^{(a)}$. The cleaning procedure uses an EnTech 3000 cleaning system that controls 1) filling the canisters with purified humid air and 2) evacuating, for several cycles with applied heat, before allowing the canister to evacuate overnight. The canister is filled a final time with purified humid air for analysis by PNL Technical Procedure PNL-TVP-01 ${ }^{\text {(b) }}$, which is a modification of U.S. Environmental Protection Agency (EPA) compendium Method TO-14. If the canister is verified as clean, free of TO-14 contaminants to a level of 5 parts per billion by volume (ppbv), the canister is evacuated to $30 \mathrm{in}$. $\mathrm{Hg}$, tagged, and stored for use in the field. Before sending the canisters out to the field for sampling, the canisters are prehumidified with $100 \mu \mathrm{L}$ of distilled water and labeled with a field-sampling identification. Canisters stored more than 30 but less than 60 days are re-evacuated and rehumidified before use. If stored more than 60 days, the canisters are recleaned and validated before use.

\subsection{Sample Analysis Method}

The SUMMA ${ }^{\mathrm{TM}}$ canister sample was analyzed according to PNL Technical Procedure PNLTVP-03, Determination of TO-14 Volatile Organic Compounds in Hanford Waste Tank Headspace Samples Using SUMMATM Passivated Canister Sampling and Gas Chromatographic-Mass Spectrometry Analysis, which is a modified version of EPA compendium Method TO-14. The method uses an EnTech cryoconcentration system interfaced with a Hewlett Packard (HP) 5971 GC/MS. The EnTech concentrator is used to pull a metered volume of sample air from the SUMMA $^{\mathrm{TM}}$ canister, cryogenically concentrate the air volume, then transfer the volume to the GC/MS for analysis. A $100-\mathrm{mL}$ volume of sample is measured and analyzed from the tank headspace. The organic components in the sampled air are separated on an analytical column, J\&W Scientific DB-1 phase, $60-\mathrm{m}$ by $0.32-\mathrm{mm}$ internal diameter with $3-\mu \mathrm{m}$ film thickness. The GC oven is programmed to run a temperature gradient beginning at $40^{\circ} \mathrm{C}$, holding for $5 \mathrm{~min}$, and ramping at $4^{\circ} \mathrm{C}$ per min to a final temperature of $260^{\circ} \mathrm{C}$, with a 5-min hold.

\subsection{Quality Assurance/Quality Control}

Before the tank sample was analyzed, a diagnostic check was performed on the GC/MS instrument by running an instrument "quick tune," as described in PNL-TVP-03. Upon satisfactory completion of the instrument diagnostic check, a blank volume of purified nitrogen was analyzed to check the cleanliness of the system. The instrument was then calibrated over 6 data points ranging from $2 \mathrm{ppbv}$ to $100 \mathrm{ppbv}$, using a standard gas mixture containing 40 volatile organic compounds listed in EPA compendium Method TO-14. A gas mixture containing bromochloromethane, 1,4difluorobenzene, and chlorobenzene- $\mathrm{d}_{5}$ was used as an internal standard (IS) for all blank, calibration

(a) Pacific Northwest Laboratory. 8/94. Cleaning SUMMATM Canisters and the Validation of the Cleaning Process, PNL-TVP-02 (Rev. 0), PNL Technical Procedure, Richland, Washington.

(b) Pacific Northwest Laboratory. 8/94. Determination of TO-14 Volatile Organic Compounds in Ambient Air Using SUMMATM Passivated Canister Sampling and Gas Chromatographic-Mass Spectrometric Analysis, PNL-TVP-01 (Rev. 0). PNL Technical Procedure, Richland, Washington. 
standard, and sample analyses. Analyte response from sample components, ISs, and standards were obtained from the extracted ion plot from their selected mass ion. The calibration curve was generated by calculating the relative response ratios of the IS to calibration standard responses and plotting the ratios against the ratio of the calibration-standard concentration (in ppbv) to the IS concentration. A least-squares linear-regression routine was applied to the data set to generate the best-fit line for each compound. The equation for that line was then used to quantify the TO-14 compounds found in the tank samples.

3.3.1 Quantitation of TO-14 Results. The quantitative-analysis results for the TO-14 volatile organic compounds were calculated directly from the calibration curve generated using the IS method described above and in PNL-TVP-03. The conversion from $\mathrm{ppmv}$ to $\mathrm{mg} / \mathrm{m}^{3}$ assumes standard temperature and pressure (STP) conditions of 760 torr and $273 \mathrm{~K}$ and was calculated directly from the following equation:

$$
\mathrm{mg} / \mathrm{m}^{3}=\frac{\mathrm{ppmv} \times \mathrm{g} \mathrm{mol} \mathrm{wt} \text { of compound }}{22.4 \mathrm{~L} / \text { mole }}
$$

3.3.2 Identification and Quantitation of Tentatively Identified Compounds. The tentatively identified compounds (TICs) are determined by mass-spectral interpretation and comparison of the spectra with the EPA/NIST/WILEY Library, which is a part of the HP 5971 instrument operating system. Chromatographic peaks with an area count greater than, or equal to, one half of the total area count of the chlorobenzene- $\mathrm{d}_{5}$ IS peak at the 20-ppbv calibration level are tentatively identified and quantitatively estimated. This standard was chosen to determine the integration cutoff as it is in the middle of the chromatographic range and not in a region typically affected by coelution of other compounds. The quality of the mass-spectral searches was then reviewed by the principal investigators before the identification was assigned to each chromatographic peak.

The concentration of each TIC was estimated using a relative response factor calculated using a corrected total peak area for the IS chlorobenzene- $d_{5}$. Specifically, the total integrated area for the chlorobenzene- $d_{5}$ peak had to be corrected for possible coeluting compounds before calculating the response factor. The corrected total peak area for the IS was calculated by multiplying the IS quantitation ion by a correction factor based on the ratio of the total integrated peak area to the quantitation ion as measured in blank runs. The corrected peak area was then used to calculate a response factor using the IS concentration in $\mathrm{mg} / \mathrm{m}^{3}$ :

$$
\text { Response Factor }=\frac{\text { IS conc. }\left(\mathrm{mg} / \mathrm{m}^{3}\right)}{\text { IS peak area }}
$$

The calculated response factor was then multiplied by the TIC peak area to give an estimated concentration for that compound. For acetone, the total peak area was multiplied by the response factor for chlorobenzene- $\mathrm{d}_{5}$ to give an estimated concentration of $0.48 \mathrm{mg} / \mathrm{m}^{3}$ (average of three samples). Internal standards bromochloromethane and difluorobenzene were not used to quantitate the TICs because coeluting compounds appeared to have greatly altered the signal of the quantitation ions for those two ISs.

The ppmv concentrations are calculated from $\mathrm{mg} / \mathrm{m}^{3}$ and the molecular weight of the analyte. 


$$
\text { TIC in ppmv }=\frac{\operatorname{TIC}\left(\mathrm{mg} / \mathrm{m}^{3}\right) \times 22.4 \mathrm{~L} / \mathrm{mole}}{\text { TIC g mol wt }}
$$

The IS level added to all blank, standard, and sample injections was $18.3 \mathrm{ppbv}$ for bromochloromethane, $20.3 \mathrm{ppbv}$ for 1,4-difluorobenzene, and $18.2 \mathrm{ppbv}$ for chlorobenzene- $\mathrm{d}_{5}$. The IS concentrations were converted from $\mathrm{ppbv}$ to $\mathrm{mg} / \mathrm{m}^{3}$ at STP using a molecular weight of 129.39 $(\mathrm{g} / \mathrm{mol})$ for bromochloromethane, 114.09 for 1,4-difluorobenzene, and 117.6 for chlorobenzene- $\mathrm{d}_{5}$.

\subsection{Analysis Results}

The results from the GC/MS analysis of the tank-headspace samples are presented in Tables 3.1 and 3.2. A compound is considered present in the tank headspace if it is detected in two or more SUMMA ${ }^{\mathrm{TM}}$ canisters. A representative total ion chromatogram showing the identity of major constituents is given in Figure 3.1. The results of the GC/MS analysis of the ambient air sample collected near Tank C-107 are presented in Table 3.3.

Table 3.1 lists the quantitative results for compounds listed in Method TO-14. Three compounds, methyl chloride, trichlorofluoromethane (FREON-11), and methyl benzene (toluene), were above the 2-ppbv calibrated instrumental detection limit. One other compound, dichlorodifluoromethane (FREON-12), was below the detection limit but was probably present in the samples.

Table 3.2 lists the semi-quantitative results for the TICs. The predominant species observed in this sample were acetone, alkylnitrate, and acetonitrile. The normal paraffin hydrocarbons (NPH), defined as $n$-alkanes from $C_{11}$ to $C_{15}$, were not seen in a significant amount in the sample. It should be noted that because the SUMMA ${ }^{\text {TM }}$ canisters were not heated at the time of analysis, the NPH concentrations listed after the retention time of decane may not be a true accounting of all the NPH in the sample. Similarly, polar compounds, which may adhere to the inside surface of the canister, may also be under represented in this analysis. The total concentration of the TIC compounds was found to be $0.974 \mathrm{mg} / \mathrm{m}^{3}$ and accounted for approximately $83 \%$ of the total concentration of all organic compounds.

Tables 3.3 lists the quantitative results for the ambient sample. Only methyl chloride was found above the instrumental detection limit. 



\subsection{Conclusions}

The concentrations of selected organic compounds were determined from in situ samples of the headspace of and the ambient air near Tank C-107.

The concentrations of acetone and methyl benzene were $41 \%$ and $10 \%$, respectively, of the total estimated concentration of all organic analytes identified. The total concentration of TO-14 analytes observed $\left(0.19 \mathrm{mg} / \mathrm{m}^{3}\right)$ accounted for $16 \%$ of the total estimated concentration. Methyl chloride was found to be slightly above the instrumental detection limit in the ambient sample. The reason for this is unknown.

\subsection{Further Reading}

Pacific Northwest Laboratory. Analytical Laboratory Procedure Compendium. Procedures PNLALO-212, -226, -271. PNL-MA-599, Richland, Washington.

Pacific Northwest Laboratory. Quality Assurance Manual, Part 2: Good Practices Standard. PNLMA-70, Part 2, Richland, Washington.

Pacific Northwest Laboratory. Quality Assurance Plan for Activities Conducted by the Analytical Chemistry Laboratory (ACL). MCS-033, Analytical Chemistry Laboratory, Richland, Washington.

Pacific Northwest Laboratory. 1994. Determination of TO-14 Volatile Organic Compounds in Hanford Waste Tank Headspace Samples Using SUMMA TM Passivated Canister Sampling and Gas Chromatographic-Mass Spectrometry Analysis, PNL-TVP-03 (Rev. 0), PNL Technical Procedure, Richland, Washington.

Pacific Northwest Laboratory. 1994. Sample Shipping and Receiving Procedure - DRAFT for PNL Waste Tank Samples. PNL-TVP-07 (Rev. 0), PNL Technical Procedure, Richland, Washington. 
Table 3.1. TO-14 Analysis Results for Samples Collected from the Headspace of Tank C-107 in SUMMA ${ }^{\text {TM }}$ Canisters on 6/17/94.

\begin{tabular}{|c|c|c|c|c|c|c|c|c|c|c|c|c|}
\hline \multirow[b]{2}{*}{ TO-14 Analyte } & \multirow{3}{*}{$\frac{\text { CAS A }}{15-71-B}$} & \multirow{3}{*}{$\frac{\text { Mol Wt }}{120.9}$} & \multicolumn{2}{|c|}{$\begin{array}{l}54029 \cdots \ldots-113^{(0)} \\
\text { PNL } 113^{(0)} \\
\text { Concontration }\end{array}$} & \multicolumn{2}{|c|}{$\begin{array}{l}S 4029 \ldots 139^{(0)} \\
\text { PNL } 139^{(0)} \\
\text { Concentration }\end{array}$} & \multicolumn{2}{|c|}{$\begin{array}{l}54029 . . . .140^{(m)} \\
\text { PNL 140 } \\
\text { Concentration }\end{array}$} & \multicolumn{4}{|c|}{$\begin{array}{l}\text { Means and } \\
\text { Standard Deviations }\end{array}$} \\
\hline & & & ppbv & $\mathrm{mg} / \mathrm{m}^{3}$ & ppbv & $\mathrm{mg} / \mathrm{m}^{3}$ & ppby & $\mathrm{mg} / \mathrm{m}^{3}$ & (ppbv) & St Dov & $\left(\mathrm{mg} / \mathrm{m}^{3}\right)$ & St Dov \\
\hline Dichlorodifluoromethane & & & & & & & & $<0.01$ & (c) & (c) & Tा & (c) \\
\hline Chloromethane & $74-87-3$ & 50.5 & 2.21 & 0.00 & 2.50 & 0.01 & 2.35 & 0.01 & 2.4 & 0.1 & 0.01 & 0.00 \\
\hline 1,2-Dichloro-1,1,2,2-tetrafluoroethane & $76-14-2$ & 170.9 & $<2$ & $<0.02$ & $<2$ & $<0.02$ & $<2$ & $<0.02$ & (c) & (c) & (c) & (c) \\
\hline Vinyl Chlorido & $75-01-4$ & 62.5 & $<2$ & $<0.01$ & $<2$ & $<0.01$ & $<\overline{2}$ & $<0.01$ & (c) & $|c|$ & $|c|$ & (c) \\
\hline Bromomothano & 74-83-9 & 94.9 & $<2$ & $<0.01$ & $<2$ & $<0.01$ & $<2$ & $<0.01$ & (c) & (c) & (c) & (c) \\
\hline Chloroethane & $75-00-3$ & 64.5 & $<2$ & $<0.01$ & $<2$ & $<0.01$ & $<2$ & $<0.01$ & (c) & (c) & (c) & (c) \\
\hline Trichlorofluoromethane & $75-69-4$ & 137.4 & 8.3 & 0.05 & 7.2 & 0.04 & 8.1 & 0.05 & 7.9 & 0.6 & 0.05 & 0.00 \\
\hline 1,1-Dichloroothano & $75-35-4$ & 96.9 & $<2$ & $<0.01$ & $<2$ & $<0.01$ & $<2$ & $<0.01$ & (c) & (c) & |c| & (c) \\
\hline Methylene Chloride & 75-09-2 & 84.9 & $<2$ & $<0.01$ & $<2$ & $<0.01$ & 2.06 & 0.01 & (c) & (c) & (c) & (c) \\
\hline 1,1,2-Trichloro-1,2,2-trifluoroethane & $76-13-1$ & 187.4 & $<2$ & $<0.02$ & $<2$ & $<0.02$ & $<2$ & $<0.02$ & (c) & (c) & (c) & (c) \\
\hline 1.1-Dichloroethane & $75-34-3$ & 99.0 & $<2$ & $<0.01$ & $<\overline{2}$ & $<0.01$ & $<2$ & $<0.01$ & (c) & (c) & |c| & (c) \\
\hline cis-1,2-Dichloroethene & $156-59.2$ & 96.9 & $<2$ & $<0.01$ & $<2$ & $<0.01$ & $<2$ & $<0.01$ & (c) & (c) & (c) & (c) \\
\hline Chloroform & $67-66-3$ & 119.4 & $<2$ & $<0.01$ & $<2$ & $<0.01$ & $<2$ & $<0.01$ & (c) & (c) & (c) & (c) \\
\hline 1,2-Dichloroethano & $107-06-2$ & 99.0 & $<2$ & $<0.01$ & $<\overline{2}$ & $<0.01$ & $<2$ & $<0.01$ & (c) & $|c|$ & (c) & (c) \\
\hline 1,1.1-Trichloroethane & $71-55-6$ & 133.4 & $<2$ & $<0.01$ & $<2$ & $<0.01$ & $<2$ & $<0.01$ & (c) & |c| & (c) & (c) \\
\hline Benzeno & $71-43-2$ & 78.1 & $<2$ & $<0.01$ & $<\overline{2}$ & $<0.01$ & $<2$ & $<0.01$ & (c) & |c| & (c) & (c) \\
\hline Carbon Tetrachlorido & $56-23-5$ & 153.8 & $<2$ & $<0.01$ & $<2$ & $<0.01$ & $<2$ & $<0.01$ & (c) & $|c|$ & (c) & (c) \\
\hline 1,2-Dichloropropano & $78-87.5$ & 113.0 & $<2$ & $<0.01$ & $<2$ & $<0.01$ & $<2$ & $<0.01$ & (c) & $|c|$ & (c) & (c) \\
\hline Trichloroethene & $79-01-6$ & 131.4 & $<2$ & $<0.01$ & $<2$ & $<0.01$ & $<2$ & $<0.01$ & (c) & (c) & (c) & (c) \\
\hline cis-1,3-Dichloropropeno & $10061-01-5$ & 111.0 & $<2$ & $<0.01$ & $<2$ & $<0.01$ & $<2$ & $<0.01$ & (c) & (c) & (c) & (c) \\
\hline trans-1,3-Dichloropropene & $10061-02-6$ & 111.0 & $<2$ & $<0.01$ & $<2$ & $<0.01$ & $<2$ & $<0.01$ & (c) & (c) & (c) & (c) \\
\hline 1,1,2-Trichloroethane & $79-00-5$ & 133.4 & $<2$ & $<0.01$ & $<2$ & $<0.01$ & $<2$ & $<0.01$ & (c) & (c) & (c) & (c) \\
\hline Toluene & 108-88-3 & 92.1 & 30.0 & 0.12 & 27.6 & 0.11 & 33.3 & 0.14 & 30.3 & 2.9 & 0.12 & 0.01 \\
\hline 1,2-Dibromoethane & $106-93-4$ & 187.9 & $<2$ & $<0.02$ & $<2$ & $<0.02$ & $<2$ & $<0.02$ & (c) & (c) & (c) & (c) \\
\hline Totrachloroethylene & $127-18-4$ & 165.8 & $<2$ & $<0.02$ & $<2$ & $<0.02$ & $<2$ & $<0.02$ & (c) & (c) & (c) & (c) \\
\hline Chlorobenzene & $108-90-7$ & 112.6 & $<2$ & $<0.01$ & $<2$ & $<0.01$ & $<2$ & $<0.01$ & (c) & (c) & (c) & (c) \\
\hline Ethylbenzene & $100-41.4$ & 106.2 & $<2$ & $<0.01$ & $<2$ & $<0.01$ & $<2$ & $<0.01$ & (c) & (c) & (c) & (c) \\
\hline p/m-Xylene & $106-42-3$ & 106.2 & $<2$ & $<0.01$ & $<2$ & $<0.01$ & $<2$ & $<0.01$ & (c) & $|c|$ & (c) & (c) \\
\hline Styrano & $100-42-5$ & 104.2 & $<2$ & $<0.01$ & $<2$ & $<0.01$ & $<2$ & $<0.01$ & (c) & (c) & (c) & (c) \\
\hline 1,1,2,2-Tetrachloroethane & $79-34-5$ & 167.9 & $<2$ & $<0.02$ & $<2$ & $<0.02$ & $<2$ & $<0.02$ & (c) & (c) & (c) & (c) \\
\hline o-Xylene & $95-47-6$ & 106.2 & $<2$ & $<0.01$ & $<2$ & $<0.01$ & $<2$ & $<0.01$ & (c) & (c) & (c) & (c) \\
\hline 1,3,5-Trimethylbenzeno & 108-67-8 & 120.2 & $<2$ & $<0.01$ & $<2$ & $<0.01$ & $<2$ & $<0.01$ & (c) & (c) & (c) & (c) \\
\hline 1,2,4-Trimethylbenzeno & $95-63-6$ & 120.2 & $<2$ & $<0.01$ & $<2$ & $<0.01$ & $<2$ & $<0.01$ & (c) & (c) & (c) & (c) \\
\hline Chloromethylbenzene, alpha & $108-67-8$ & 126.6 & $<2$ & $<0.01$ & $<2$ & $<0.01$ & $<2$ & $<0.01$ & (c) & (c) & (c) & (c) \\
\hline 1.3-Dichlorobenzene & 541-73-1 & 147.0 & $<2$ & $<0.01$ & $<2$ & $<0.01$ & $<2$ & $<0.01$ & (c) & (c) & (c) & (c) \\
\hline 1.4-Dichlorobenzene & $106-46-7$ & 147.0 & $<2$ & $<0.01$ & $<2$ & $<0.01$ & $<2$ & $<0.01$ & (c) & (c) & (c) & (c) \\
\hline 1.2-Dichlarobenzene & $95-50-1$ & 147.0 & $<2$ & $<0.01$ & $<2$ & $<0.01$ & $<2$ & $<0.01$ & (c) & (c) & (c) & (c) \\
\hline 1,2.4-Trichlorobenzene & $120-82-1$ & 181.5 & $<2$ & $<0.02$ & $<2$ & $<0.02$ & $<2$ & $<0.02$ & (c) & (c) & (c) & (c) \\
\hline Hexachloro-1,3-butadieno & $87 \cdot 68-3$ & 260.8 & $<2$ & $<0.02$ & $<2$ & $<0.02$ & $<2$ & $<0.02$ & (c) & (c) & (c) & (c) \\
\hline
\end{tabular}

(a) WHC sample identification number.

(c) AvL canister number.

(c) Averago and standerd deviation data is not meaningful for this analyte. 


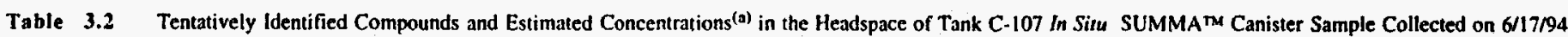

\begin{tabular}{|c|c|c|c|c|c|c|c|c|c|c|c|c|c|}
\hline \multirow[b]{2}{*}{ Tentatively Identified Compound (d) } & \multirow[b]{2}{*}{ CAS No. ${ }^{(d)}$} & \multirow[b]{2}{*}{ Mol Wt } & \multirow[b]{2}{*}{ Ret Time } & \multicolumn{2}{|c|}{ 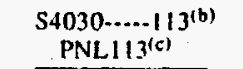 } & \multicolumn{2}{|c|}{$\begin{array}{c}S 4029 \ldots 140^{(b)} \\
\text { PNLI } 40^{(c)}\end{array}$} & \multicolumn{2}{|c|}{$\begin{array}{l}\text { S4029....139(b) } \\
\text { PNL139(c) }\end{array}$} & \multicolumn{4}{|c|}{ Means and Standard Deviation } \\
\hline & & & & $\left(m g / m^{\prime}\right)$ & (ppmv) & $\left(\overline{m g} / \mathrm{m}^{2}\right)$ & (ppmv) & $\left(\mathrm{mg} / \mathrm{m}^{2}\right)$ & (ppmv) & $\left(\overline{\left.\mathrm{mg} / \mathrm{m}^{3}\right)}\right.$ & (St Dev) & (ppmv) & (St Dev) \\
\hline Carbon Dioxide & $124-38-9$ & $\$ 4$ & 3.141 & (e) & (e) & (e) & (e) & (e) & (e) & (e) & & (e) & \\
\hline Acetonitrile & $75-05-8$ & 41 & 7.969 & 0.175 & 0.095 & 0.141 & 0.077 & 0.113 & 0.062 & 0.143 & 0.031 & 0.078 & 0.017 \\
\hline Acetone & $67-64-1$ & 58 & 8.514 & 0.538 & 0.208 & 0.484 & 0.187 & 0.411 & 0.159 & 0.478 & 0.064 & 0.184 & 0.025 \\
\hline Alkyl Nitrate & (g) & (g) & 10.532 & 0.110 & (g) & 0.093 & $(g)$ & 0.085 & g & 0.096 & 0.013 & (g) & \\
\hline Propanenitrile & $107.12-0$ & 55 & $11: 952$ & 0.060 & 0.025 & 0.066 & 0.027 & 0.078 & 0.032 & 0.068 & 0.009 & 0.028 & 0.004 \\
\hline 2-Butanone & $78-93-3$ & 72 & 13.63 & $<0.032$ & $<0.010$ & 0.056 & 0.017 & 0.056 & 0.018 & 0.037 & 0.032 & 0.012 & 0.010 \\
\hline Bromochloromethane (IS) & $74-97-5$ & 128 & 14.875 & (f) & (f) & (f) & (t) & (f) & (f) & (f) & (n) & (f) & (t) \\
\hline Alkyl Nitrate & (g) & (g) & 15.143 & 0.064 & (g) & 0.067 & (g) & 0.072 & (g) & 0.068 & 0.004 & (g) & \\
\hline 1.4 Difluorobenzene (IS) & $540-36-3$ & 114 & 18.601 & (f) & (f) & (f) & (f) & $(f)$ & (f) & (f) & (f) & (f) & (f) \\
\hline Hexanal & $66-25-1$ & 100 & 24.96 & $<0.045$ & $<0.010$ & 0.051 & 0.012 & $<0.045$ & $<0.010$ & 0.051 & & 0.012 & \\
\hline d5-Chlorobenzene (IS) & $3114.55-4$ & 117 & $28.1+3$ & (f) & (f) & $(f)$ & (n) & $(\mathrm{f})$ & (f) & (f) & (n) & (f) & (ก) \\
\hline Nonanal & $124-19-6$ & 142 & 39.78 & $<0.063$ & $<0.010$ & 0.062 & 0.010 & $<0.063$ & $<0.010$ & 0.031 & 0.044 & 0.005 & 0.007 \\
\hline
\end{tabular}

Semi-quantitative estimate calculated using concentration of closest eluting internal standard. PNL sample identfesion number

Obtained by mass spectral interpretation amd comparison with the EPA/NIST/WILEY Library.

the analytical method used.

Conention information for internal standards are determined by direct calibration. 
Table 3.3. To-14 Analysis Results for Ambient Air Collected Near Tank C-107 in SUMMA ${ }^{\text {TM }}$ Canister on 6/17/9

\begin{tabular}{|c|c|c|c|c|}
\hline & & & $\begin{array}{l}\text { S4041 } \\
\text { PNL } 138^{\circ} \\
\text { Ambient } \\
\text { Concentra }\end{array}$ & $138^{(0)}$ \\
\hline To-14 Anaiyte & CAS: & Mol Wt & epbr & $\mathrm{mg} / \mathrm{m}^{3}$ \\
\hline Dichlorodifluoromethane & $75-71-8$ & 120.9 & $<2$ & $<0.01$ \\
\hline Chloromethane & $74-87-3$ & 50.5 & 2.4 & 0.01 \\
\hline $\begin{array}{l}\text { 1.2-Dichloro-1,1,2,2-tetrafluoroethane } \\
\text { Vinyl Chloride }\end{array}$ & $\begin{array}{l}76-14-2 \\
75-01-4\end{array}$ & $\begin{array}{c}170.9 \\
62.5\end{array}$ & $\begin{array}{l}<2 \\
<2\end{array}$ & $\begin{array}{l}<0.02 \\
<0.01\end{array}$ \\
\hline Bromomethane & $74-83-9$ & 94.9 & $<2$ & $<0.01$ \\
\hline Chloroothane & $75-00-3$ & 64.5 & $<2$ & $<0.01$ \\
\hline Trichlorofluoromethane & $75-69 \cdot 4$ & 137.4 & $<2$ & $<0.01$ \\
\hline 1,1-Dichlaroethene & $75 \cdot 35 \cdot 4$ & 86.9 & $<2$ & $<0.01$ \\
\hline Methylene Chloride & $75-09 \cdot 2$ & 84.9 & $<2$ & $<0.01$ \\
\hline 1,1,2-Trichioro-1,2,2-trifluoroethane & $76-13-1$ & 187.4 & $<2$ & $<0.02$ \\
\hline $\begin{array}{l}\text { 1.1-Dichloroethane } \\
\text { cie-1.2-Dichloroethene }\end{array}$ & $\begin{array}{l}75-34-3 \\
156-59-2\end{array}$ & $\begin{array}{l}99.0 \\
96.9\end{array}$ & $\begin{array}{l}<2 \\
<2\end{array}$ & $\begin{array}{l}<0.01 \\
<0.01\end{array}$ \\
\hline Chloroform & $67-66-3$ & 119.4 & $<2$ & $<0.01$ \\
\hline 1,2-Dichloroethane & $107-06-2$ & 99.0 & $<2$ & $<0.01$ \\
\hline 1,1,1-Trichloroethane & 71.55 .6 & 133.4 & $<2$ & $<0.01$ \\
\hline Benzene & $71-43-2$ & 78.1 & $<2$ & $<0.01$ \\
\hline Carbon Tetrachioride & $56-23-5$ & 153.8 & $<2$ & $<0.01$ \\
\hline 1.2-Dichloropropano & $78-87-5$ & 113.0 & $<2$ & $<0.01$ \\
\hline Trichloroethene & $79-01-6$ & 131.4 & $<2$ & $<0.01$ \\
\hline cis-1,3-Dichloropropene & $10061-01-5$ & 111.0 & $<2$ & $<0.01$ \\
\hline trans-1,3-Dichloropropene & 10061.02 .6 & 111.0 & $<2$ & $<0.01$ \\
\hline 1.1.2-Trichloroethane & $79-00-5$ & 133.4 & $<2$ & $<0.01$ \\
\hline Toluene & $108-88-3$ & 92.1 & $<2$ & $<0.01$ \\
\hline 1,2-Dibromoethane & $106-93-4$ & 187.9 & $<2$ & $<0.02$ \\
\hline Totrachloroethyiene & $127-18-4$ & 165.8 & $<2$ & $<0.02$ \\
\hline Chlorobenzene & $108-90.7$ & 112.6 & $<2$ & $<0.01$ \\
\hline Ethylbenzene & $100-41-4$ & 106.2 & $<2$ & $<0.01$ \\
\hline$p / m-X y l e n e^{|c|}$ & $106-42-3$ & 106.2 & $<2$ & $<0.01$ \\
\hline Styrene & $100-42.5$ & 104.2 & $<2$ & $<0.01$ \\
\hline 1,1,2,2-Tetrachloroethane & $79-34-5$ & 167.9 & $<2$ & $<0.02$ \\
\hline o.Xylene & $95-47.6$ & 106.2 & $<2$ & $<0.01$ \\
\hline 1,3,5-Trimethylbenzene & $108-67 \cdot 8$ & 120.2 & $<2$ & $<0.01$ \\
\hline 1,2,4-Trimethylbenzene & & & $<2$ & $<0.01$ \\
\hline $\begin{array}{l}\text { Chloromethylbenzene, alpha (Benzyl } \\
\text { 1.3-Dichlorobenzene }\end{array}$ & $\begin{array}{l}108-67-8 \\
541-73-1\end{array}$ & $\begin{array}{l}126.6 \\
147.0\end{array}$ & $\begin{array}{l}<2 \\
<2\end{array}$ & $\begin{array}{l}<0.01 \\
<0.01\end{array}$ \\
\hline 1,4-Dichlorobenzeno & $106-46-7$ & 147.0 & $<2$ & $<0.01$ \\
\hline 1,2-Dichlorobenzene & $95 \cdot 50-1$ & 147.0 & $<2$ & $<0.01$ \\
\hline 1,2,4-Trichlorobenzene & $120-82.1$ & 181.5 & $<2$ & $<0.02$ \\
\hline Hexachloro-1,3-butadiene & $87-68-3$ & 260.8 & $<2$ & $<0.02$ \\
\hline
\end{tabular}

(a) WHC sample identification number.

(b) PNL canister number.

(c) $m$-xylene and p-xylene coelute; reported concentrations are the sum of these two compounds. 


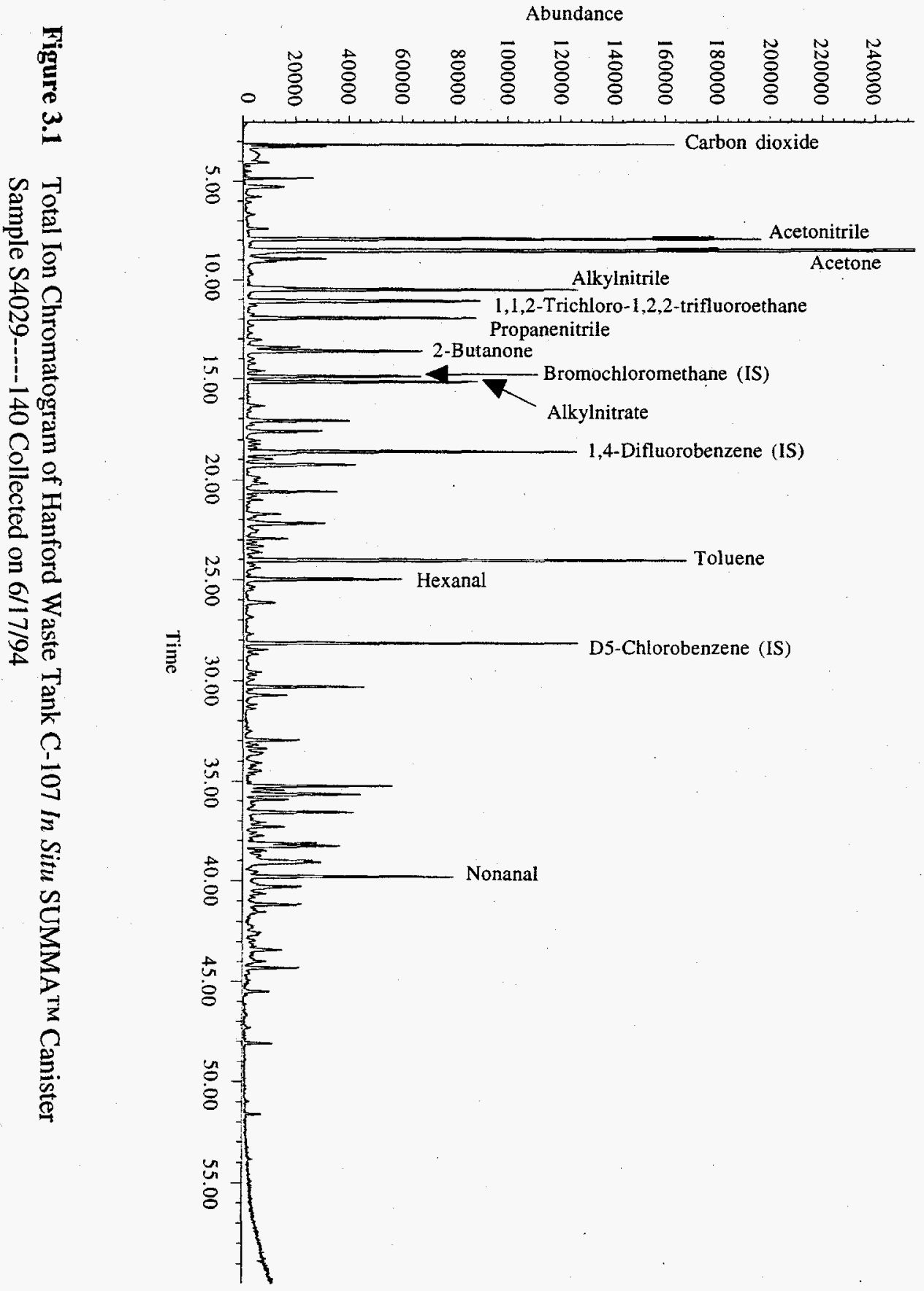




\section{Distribution}

No. of

Copies

\section{Offsite}

2 DOE Office of Scientific and Technical Information

R. A. Jenkins

Oak Ridge National Laboratory

P.O. Box 2008

Building 4500-5, MS 6120

Oak Ridge, Tennessee 37831-6120
No. of

Copies

Onsite

2 DOE Richland Operations Office

J. M. Clark, S7-54

T. Noble, $57-54$

Corps of Engineers

T. W. Gardner-Clayson, A5-19

4 Westinghouse Hanford Company

H. Babad, R2-78

J. E. Meacham, S7-15

J. W. Osborne, S7-15 (2)

$28 \quad$ Pacific Northwest Laboratory

S. C. Goheen, P8-08 (20)

J. L. Huckaby, K6-55

M. W. Ligotke, P7-59

Publishing Coordination

Technical Report Files (5)

Dist. 1 